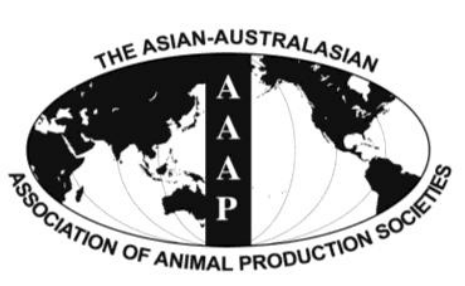

Open Access

Asian Australas. J. Anim. Sci.

Vol. 28, No. 3 : 351-359 March 2015

http://dx.doi.org/10.5713/ajas.14.0504

www.ajas.info

pISSN 1011-2367 elSSN 1976-5517

\title{
Effects of Corn and Soybean Meal Types on Rumen Fermentation, Nitrogen Metabolism and Productivity in Dairy Cows
}

\author{
J. S. Shen ${ }^{1,2}$, L. J. Song ${ }^{1}$, H. Z. Sun ${ }^{1}$, B. Wang ${ }^{1}$, Z. Chai ${ }^{1}$, B. Chacher ${ }^{1,3}$, and J. X. Liu ${ }^{1, *}$ \\ ${ }^{1}$ Institute of Dairy Science, MoE Key Laboratory of Molecular Animal Nutrition, \\ College of Animal Sciences, Zhejiang University, Hangzhou 310058, China
}

\begin{abstract}
Twelve multiparous Holstein dairy cows in mid-lactation were selected for a replicated $4 \times 4$ Latin square design with a 2 $\times 2$ factorial arrangement to investigate the effects of corn and soybean meal (SBM) types on rumen fermentation, $\mathrm{N}$ metabolism and lactation performance in dairy cows. Two types of corn (dry ground [DGC] and steam-flaked corn [SFC]) and two types of SBM (solvent-extracted and heat-treated SBM) with different ruminal degradation rates and extents were used to formulate four diets with the same basal ingredients. Each period lasted for 21 days, including $14 \mathrm{~d}$ for adaptation and $7 \mathrm{~d}$ for sample collection. Cows receiving SFC had a lower dry matter (DM) and total $\mathrm{N}$ intake than those fed DGC. However, the milk yield and milk protein yield were not influenced by the corn type, resulting in higher feed and $\mathrm{N}$ utilization efficiency in SFC-fed cows than those receiving DGC. Ruminal acetate concentrations was greater and total volatile fatty acids concentrations tended to be greater for cows receiving DGC relative to cows fed SFC, but milk fat content was not influenced by corn type. The SFC-fed cows had lower ruminal ammonia-N, less urea N in their blood and milk, and lower fecal N excretion than those on DGC. Compared with solvent-extracted SBM-fed cows, cows receiving heat-treated SBM had lower microbial protein yield in the rumen, but similar total tract apparent nutrient digestibility, $\mathrm{N}$ metabolism measurements, and productivity. Excessive supply of metabolizable protein in all diets may have caused the lack of difference in lactation performance between SBM types. Results of the present study indicated that increasing the energy degradability in the rumen could improve feed efficiency, and reduce environmental pollution. (Key Words: Corn, Soybean Meal, Nitrogen Metabolism, Productivity, Dairy Cow)
\end{abstract}

\section{INTRODUCTION}

For ruminants, the low efficiency of nitrogen $(\mathrm{N})$ utilization (around 25\%) compared with other animals has implications for the production performance and environment (Calsamiglia et al., 2010). Furthermore, excess dietary protein can impair reproduction and contribute to lameness (Sinclair et al., 2014). Therefore, the goal of ruminant protein nutrition is to provide adequate amounts

\footnotetext{
* Corresponding Author: J. X. Liu. Tel: +86-571-88982097, Fax: +86-571-88982930, E-mail: liujx@zju.edu.cn

${ }^{2}$ Laboratory of Gastrointestinal Microbiology, College of Animal Science and Technology, Nanjing Agricultural University, Nanjing 210095, China.

${ }^{3}$ Faculty of Veterinary and Animal Sciences, Lasbela University of Agriculture, Water and Marine Sciences, Uthal Balochitan 90150, Pakistan.

Submitted Jul. 9, 2014; Revised Sept. 5, 2014; Accepted Oct. 8, 2014
}

of RDP for optimal ruminal efficiency and to obtain the desired animal productivity with a minimum amount of dietary CP (NRC, 2001). Rumen microbes use carbohydrates as the major energy source. If the rate of protein degradation exceeds carbohydrate fermentation, large quantities of $\mathrm{N}$ are converted into ammonia-N; likewise, when the rate of carbohydrate fermentation exceeds protein degradation, inefficient microbial protein (MCP) synthesis may occur (Bach et al., 2005). Therefore, the synchronization of ruminal degradability of carbohydrate and protein should maximize MCP synthesis to support animal growth and milk production (Casper et al., 1999).

Rumen MCP is the major source of intestinally absorbed protein in dairy cows, supplying an average of $59 \%$ of the non-ammonia $\mathrm{N}$ absorbed from the small intestine (Clark et al., 1992). Nutrient synchrony should theoretically increase MCP synthesis efficiency and animal

Copyright $@ 2015$ by Asian-Australasian Journal of Animal Sciences This is an open-access article distributed under the terms of the Creative Commons Attribution Non-Commercial License (http://creativecommons.org/licenses/by-nc/3.0/), which permits unrestricted non-commercial use, distribution, and reproduction in any medium, provided the original work is properly cited. 
productivity, but synchronization is elusive in practice (Hall and Huntington, 2008). Positive effects have been observed in many studies (Sinclair et al., 1993; Rotger et al., 2006) by changing feed ingredients, but others have not (Henning et al., 1993; Casper et al., 1999). Nevertheless, it is difficult to clarify whether increased MCP synthesis resulting from the provision of different ingredients is an effect of synchrony or due to the ingredient manipulation (level and type; Dewhurst et al., 2000).

Corn is the primary energy source, and soybean meal (SBM) is the main protein source, for dairy cows in many countries. Feed processing methods affect the rate and extent of ruminal degradation of corn and SBM, leading to changes in energy and $\mathrm{N}$ utilization efficiency. Processing of corn and SBM may change the chemical structure of some components. Steam-flaked corn (SFC) exhibited greater ruminal starch degradability than dry ground corn (DGC; Huntington, 1997), and heat-treated SBM (HSBM) had lower CP degradability than solvent-extracted SBM (SSBM; NRC, 2001). Synchronizing supply of energy and $\mathrm{N}$ by changing processing method for corn and SBM may minimize the effects of ingredient manipulation on MCP synthesis and animal productivity. Therefore, the objective of this study was to investigate the effects of varied corn and SBM types on rumen fermentation, $\mathrm{N}$ metabolism and productivity in dairy cows.

\section{MATERIAL AND METHODS}

\section{Animals, diets and experimental design}

The experimental procedures used in this study were approved by the Animal Care Committee of Zhejiang University, and they were carried out in accordance with the university's guidelines for animal research. Health of cows was monitored continuously before and during the entire experimental period.

Twelve multiparous Holstein dairy cows (body weight $[\mathrm{BW}]=594 \pm 31 \mathrm{~kg}$; days in milk $[\mathrm{DIM}]=130 \pm 14 \mathrm{~d}$; milk yield $=31.3 \pm 1.8 \mathrm{~kg}$ ) were used in a replicated $4 \times 4$ Latin square design with $21-\mathrm{d}$ periods and a $2 \times 2$ factorial dietary treatment arrangement. Each experimental period consisted of $14 \mathrm{~d}$ of dietary adaptation and $7 \mathrm{~d}$ for sample and data collection. Cows were housed in individual tie stalls and had continuous access to water from water bowls. Treatment factors were i) corn type (DGC [Hangzhou Hangjiang Dairy Farm, China] vs SFC [Kaite Feed Corp., Hebei, China; the flake density was $360 \mathrm{~g} / \mathrm{L}]$ ) and ii) SBM type (SSBM [Hangzhou Hangjiang Dairy Farm, China] vs HSBM [Shanghai Bright Holstan Co. Ltd., Shanghai, China]), which differed in their ruminal degradation rate and extent. Ingredients and chemical compositions of diets are shown in Table 1. All diets had similar CP and energy contents and were formulated to meet the net energy for
Table 1. Diet ingredients and chemical compositions ${ }^{1}$

\begin{tabular}{|c|c|c|c|c|}
\hline \multirow{2}{*}{ Item } & \multicolumn{2}{|c|}{ SFC } & \multicolumn{2}{|c|}{ DGC } \\
\hline & SSBM & HSBM & SSBM & HSBM \\
\hline \multicolumn{5}{|l|}{ Ingredients (\% of DM) } \\
\hline Corn silage & 25.0 & 25.0 & 25.0 & 25.0 \\
\hline Chinese wild rye & 8.0 & 8.0 & 8.0 & 8.0 \\
\hline Alfalfa hay & 17.0 & 17.0 & 17.0 & 17.0 \\
\hline Wheat bran & 4.0 & 4.0 & 4.0 & 4.0 \\
\hline Dry ground corn & - & - & 27.0 & 27.0 \\
\hline Steam-flaked corn & 27.0 & 27.0 & - & - \\
\hline $\begin{array}{c}\text { Solvent-extracted } \\
\text { soybean meal }\end{array}$ & 9.0 & - & 9.0 & - \\
\hline Heat-treated soybean meal & - & 9.0 & - & 9.0 \\
\hline Cottonseed meal & 6.0 & 6.0 & 6.0 & 6.0 \\
\hline $\operatorname{Premix}^{1}$ & 4.0 & 4.0 & 4.0 & 4.0 \\
\hline \multicolumn{5}{|l|}{ Nutrient composition } \\
\hline $\mathrm{DM}(\%)$ & 48.9 & 48.7 & 48.9 & 48.8 \\
\hline $\mathrm{CP}(\%$ of $\mathrm{DM})$ & 15.6 & 15.6 & 15.7 & 15.7 \\
\hline $\operatorname{Starch}^{2}(\%$ of DM) & 25.7 & 26.1 & 23.8 & 23.7 \\
\hline $\mathrm{NFC}^{3}(\%$ of $\mathrm{DM})$ & 37.4 & 37.2 & 36.9 & 36.8 \\
\hline $\mathrm{RDP}(\%$ of DM) & 9.0 & 7.9 & 9.6 & 8.6 \\
\hline RUP (\% of DM) & 6.6 & 7.8 & 6.2 & 7.1 \\
\hline $\mathrm{MP}(\mathrm{g} / \mathrm{d})$ & 162 & 257 & 78 & 213 \\
\hline NDF (\% of DM) & 35.9 & 35.7 & 36.3 & 36.2 \\
\hline $\mathrm{ADF}(\%$ of $\mathrm{DM})$ & 20.2 & 20.8 & 20.3 & 20.9 \\
\hline $\mathrm{NEl}^{4}$ (Mcal/kg DM) & 1.55 & 1.57 & 1.54 & 1.56 \\
\hline
\end{tabular}

SFC, steam-flaked corn; DGC, dry ground corn; SSBM, solvent-extracted soybean meal; HSBM, heat-treated soybean meal; DM, dry matter; CP, crude protein; NFC, non-fiber carbohydrate; RDP, ruminally degradable protein; RUP, ruminally undegradable protein; MP, metabolizable protein; $\mathrm{NDF}$, neutral detergent fiber; ADF, acid detergent fiber; NEl, net energy for lactation.

${ }^{1}$ Formulated to provide (per $\mathrm{kg}$ of DM) $1 \% \mathrm{CP}, 15 \%$ ether extract, $6 \%$ crude fiber, $7 \% \mathrm{Ca}, 1.3 \% \mathrm{P}, 10 \%$ salt, $3 \% \mathrm{Mg}, 1.5 \% \mathrm{~K}, 1 \% \mathrm{Met}, 260 \mathrm{mg}$ of $\mathrm{Cu}, 260 \mathrm{mg}$ of $\mathrm{Fe}, 1,375 \mathrm{mg}$ of $\mathrm{Zn}, 500 \mathrm{mg}$ of $\mathrm{Mn}, 112,000 \mathrm{IU}$ of vitamin A, 29,500 IU of vitamin $\mathrm{D}_{3}$, and $700 \mathrm{IU}$ of vitamin $\mathrm{E}$.

${ }^{2}$ The starch contents of DGC and SFC were 64.5 and $72.1 \%$ of the DM, respectively; the CP content of SSBM and HSBM were 50.0 and $50.5 \%$ of DM, respectively.

${ }^{3} \mathrm{NFC}=100-(\% \mathrm{NDF}+\% \mathrm{CP}+\%$ gat $+\%$ ash $)$

${ }^{4}$ Calculated based on individual feedstuffs by the Ministry of Agriculture, China (2004), except for protein degradability of SSBM and HSBM, which were determined in situ using a nylon bag technique.

lactation requirements of cows weighing $600 \mathrm{~kg}$, averaging 130 DIM and producing $31 \mathrm{~kg}$ of milk (Ministry of Agriculture of P. R. China, 2004). Diets were offered three times daily at 0630, 1330, and $2000 \mathrm{~h}$ and there was approximately $5 \%$ feed refusal. Cows were milked three times daily at 0700, 1400, and $2030 \mathrm{~h}$.

Ruminal degradation data for two corn types and two SBM types were determined in situ by using the nylon bag technique (Ørskov et al., 1980). Approximately $5 \mathrm{~g}$ of each sample was placed in a nylon bag $(10 \times 20 \mathrm{~cm} ; 50-\mu \mathrm{m}$ pore size; Ankom Technology Corp., Macedon, NY, USA) with 6 replicates in each incubation time. Bags were tied to the end of a 40-cm nylon line and attached to a stainless-steel 
weight, and then placed in the rumen ventral sac of three ruminally cannulated Chinese Holstein cows $(\mathrm{BW}=$ $634 \pm 17 \mathrm{~kg}$; DIM $=83 \pm 7 \mathrm{~d}$; milk yield $=21.4 \pm 4.2 \mathrm{~kg}$ ). Diet ingredients for cannulated cows included $45.0 \%$ concentrate, $17.0 \%$ corn silage, $28.0 \%$ alfalfa hay, and $10.0 \%$ Chinese wild rye on a DM basis. The bags with samples were removed from the rumen after $0,2,4,8,16,24$, and $36 \mathrm{~h}$ incubation. Bags were rinsed thoroughly, dried and weighed. The in situ digestion parameters were estimated using the nonlinear model described by Ørskov et al. (1980).

\section{Sampling and measurement}

The TMR offered and refused were weighed from d 16 to 19 of each period to determine DMI. Samples of TMR and ort were collected daily from d 16 to 19 of each period. Fecal grab samples were taken three times daily from the rectum of each cow at 0630,1230 , and $1830 \mathrm{~h}$ on d 17, 18, and 19 of each period. Daily feed, orts and fecal samples were composited per cow for each experimental period, and subsamples were subsequently stored at $-20^{\circ} \mathrm{C}$ until analysis. At the end of the experiment, all samples were thawed and dried at $65^{\circ} \mathrm{C}$ for $48 \mathrm{~h}$. Dried samples were ground through a 1-mm screen in a Cyclotec mill (Tecator 1093; Tecator AB, Hoganas, Sweden) before analysis. All samples were analyzed for DM (method 967.03), OM (method 942.05), and CP (method 984.13; AOAC, 1990). Contents of ADF and NDF were determined according to Van Soest et al. (1991). Starch concentration was determined using a colorimetric method (Bertrand et al., 2003). The acid insoluble ash in diets and feces were analyzed using the method described by Van Keulen and Young (1977), and results were used as internal markers for estimating apparent nutrient digestibility (Zhong et al., 2008).

Milk yield was recorded and milk samples were collected on d 18, 19, and 20 of each period. Two $50 \mathrm{~mL}$ of milk samples were collected from individual cows at the 3 daily milkings and aliquots were mixed completely at a $4: 3: 3$, a ratio reflecting the milk yield of 3 milkings. One aliquot was mixed with Bronopol (a milk preservative; D \& F Control Systems Inc., San Ramon, CA, USA) and stored at $4^{\circ} \mathrm{C}$ for later analysis of protein, fat, and lactose contents using infrared analysis (Foss Milk-O-Scan, Foss Food Technology Corp., Eden Prairie, MN, USA). Another aliquot without Bromopol was stored at $-20^{\circ} \mathrm{C}$ immediately for milk urea nitrogen (MUN) analysis using colorimetric method.

Spot urine samples were collected three times daily before each feeding (at about 0600, 1200, and $1800 \mathrm{~h}$ ) on d 17, 18, and 19 of each period. Fresh urine samples were acidified by diluting one volume of urine with four volumes of $0.036 \mathrm{~mol} \mathrm{H}_{2} \mathrm{SO}_{4} / \mathrm{L}$. Daily urine samples were pooled for each cow during each collection period, and subsamples were stored at $-20^{\circ} \mathrm{C}$ for later analysis. At the end of the experiment, all urine samples were thawed at $25^{\circ} \mathrm{C}$ and filtered through Whatman no. 1 filter paper. Filtrates were then analyzed for total $\mathrm{N}$ using Kjieldahl method (method 984.13; AOAC, 1990). Purine derivatives were analyzed by the procedure of Chen and Gomes (1992) and creatinine was analyzed using a picric acid assay (Oser, 1965). Urine volumes were computed using creatinine as a marker and by assuming a creatinine excretion of $29 \mathrm{mg} / \mathrm{kg}$ of BW per day (Valadares et al., 1999). Urinary purine derivatives were used to estimate the MCP yield in the rumen (Chen and Gomes, 1992).

Blood samples $(9 \mathrm{~mL})$ were collected from the coccygeal artery of each cow in heparinized evacuated tubes at approximately $3 \mathrm{~h}$ after morning feeding on d 20 of each period. The sample was then centrifuged at $3,000 \times \mathrm{g}$ for $15 \mathrm{~min}$ to obtain the plasma. All plasma samples were stored at $-20^{\circ} \mathrm{C}$ for later analysis of blood urea nitrogen (BUN) (colorimetric method; Rahmatullah and Boyde, 1980), glucose (enzymatic method; Barham and Trinder, 1972) and insulin (double-antibody radioimmunoassay; Daniels et al., 2008).

Ruminal contents were collected using an oral stomach tube (Shen et al., 2012) approximately $3 \mathrm{~h}$ after the morning feeding on d 21 of each period and were strained through four layers of cheesecloth. The $\mathrm{pH}$ of ruminal fluids was measured immediately with a portable $\mathrm{pH}$ meter (STARTER 300, Ohaus Instruments Co. Ltd., Shanghai, China). Five $\mathrm{mL}$ of filtrate was preserved by adding $1 \mathrm{~mL}$ of $25 \% \quad \mathrm{HPO}_{3}$ for determination of VFA by gas chromatography (GC-8A, Shimadzu, Kyoto, Japan) as described by $\mathrm{Hu}$ et al. (2005). Another $5 \mathrm{~mL}$ of filtrate was stored at $-20^{\circ} \mathrm{C}$ for subsequent analysis of ammonia-N using alkaline phenolhypochlorite colorimetric procedure of Chaney and Marbach (1962).

\section{Statistical analyses}

Statistical analyses were carried out with SAS software (Statistical Analysis Systems package 8.01, Cary NC, USA). Preliminary data screening revealed that all dependent variables were normally distributed. Ruminal degradation parameters $(a, b, c)$ for DM, starch or $\mathrm{CP}$ and their effective degradability were analyzed using the SAS general linear model procedure.

Data for plasma metabolites, rumen fermentation, nutrient digestion, N metabolism, and MCP yield were analyzed as a replicated Latin square using the mixed procedure of SAS. The model included square, period, corn, SBM, and corn $\times$ SBM interaction as fixed effects, with cow within square as random effect. Data for DMI, milk yield, milk composition and feed efficiency were analyzed with day as repeated measures using covariance type autoregressive (1), which provided the best fit according to 
Akaike's information criterion and Sawa's Bayesian information criterion. Fixed effects within the model included square, period, day, corn, SBM, interactions for corn $\times$ SBM, corn $\times$ day, SBM $\times$ day, and corn $\times$ SBM $\times$ day, with cow within square and $\operatorname{corn} \times \mathrm{SBM} \times$ period $\times$ cow within square as random effects. Degrees of freedom were calculated using the Kenward-Roger option. Differences were considered to be statistically significant when the pvalues were $\leq 0.05$, and trends were declared at $0.05<p \leq 0.10$. All reported values are least squares means unless otherwise stated.

\section{RESULTS AND DISSCUSSION}

\section{Dietary characteristics and ruminal degradation data for corn and soybean meal}

Ingredients and nutrient composition of diets are shown in Table 1. The SFC had a higher starch content than DGC (72.1\% vs $64.5 \%$ of DM), leading to a higher starch content in SFC than DGC-based diets. The difference in starch content between two types of corn may be related with corn genotype, growing environment, or harvest, because they were obtained from the different sources. The HSBM had a similar CP (50.5\% vs $50.0 \%$ of DM), but was higher in RUP content compared with SSBM (Table 2), resulting in RDP/RUP differences among diets. All the other nutrient contents were similar.

The in situ digestion results showed that the SFC had greater starch degradability than DGC (66.9\% vs $46.9 \%$; Table 2). Rooney and Pflugfelder (1986) suggested that the increased starch degradability of SFC might be caused by the disruption of the protein matrix surrounding the endosperm starch granules and disorganization in the starch granules. Heat treatment resulted in lower CP degradability in HSBM than in SSBM (29.3\% vs $54.2 \%$; Table 2). The decreased degradability of HSBM was mainly attributed to the denaturation of proteins, and the formation of proteincarbohydrate (by Maillard reactions) and protein-protein cross-links (NRC, 2001). Differences in the ruminal degradation rate and extent for corn starch or SBM CP resulted in four diets with different nutrient synchrony.

Dry matter intake, milk yield, milk composition and plasma metabolites

Cows receiving SFC had lower DMI than those fed DGC ( $<<0.05$; Table 3). However, milk yield and 4\% FCM were not affected by corn type ( $>0.05)$, resulting in greater feed efficiency $(44.94 \%$, milk yield/DMI) for cows receiving SFC relative to DGC-fed cows $(\mathrm{p}<0.05)$. No significant interactions with corn and SBM were detected for DMI, milk yield and milk compositions ( $p>0.05$ ). In previous studies, the most common response to corn steam flaking is an increased milk yield with increased DMI (Yu
Table 2. Degradation constants of DM, CP, and starch based on the equation $\mathrm{p}=a+b(1-\exp [-c \mathrm{t}])^{1}$, and their effective degradability (ED) for different SBM or corn types

\begin{tabular}{|c|c|c|c|c|}
\hline \multirow{2}{*}{ Item } & \multicolumn{2}{|c|}{ SBM or corn types } & \multirow{2}{*}{ SEM } & \multirow{2}{*}{ p-value } \\
\hline & Type 1 & Type 2 & & \\
\hline SBM type & SSBM & HSBM & & \\
\hline \multicolumn{5}{|c|}{ DM degradation } \\
\hline$a(\%)$ & 0.35 & 0.32 & 0.22 & 0.92 \\
\hline$b(\%)$ & 99.69 & 99.65 & 0.22 & 0.92 \\
\hline$c(\% / \mathrm{h})$ & 5.80 & 2.71 & 0.45 & $<0.01$ \\
\hline $\mathrm{ED}(\%)$ & 49.12 & 31.12 & 2.37 & $<0.01$ \\
\hline \multicolumn{5}{|c|}{$\mathrm{CP}$ degradation } \\
\hline$a(\%)$ & 8.12 & 3.23 & 1.86 & 0.16 \\
\hline$b(\%)$ & 90.89 & 97.43 & 2.08 & 0.03 \\
\hline$c(\% / \mathrm{h})$ & 6.24 & 2.17 & 0.84 & 0.04 \\
\hline $\mathrm{ED}(\%)$ & 54.19 & 29.26 & 2.64 & $<0.01$ \\
\hline Corn type & DGC & SFC & & \\
\hline \multicolumn{5}{|c|}{ DM degradation } \\
\hline$a(\%)$ & 2.27 & 5.89 & 1.15 & 0.09 \\
\hline$b(\%)$ & 93.06 & 78.27 & 5.81 & 0.14 \\
\hline$c,(\% / \mathrm{h})$ & 4.17 & 9.85 & 2.60 & 0.19 \\
\hline $\mathrm{ED}(\%)$ & 39.25 & 50.93 & 3.27 & 0.07 \\
\hline \multicolumn{5}{|c|}{ Starch degradation } \\
\hline$a(\%)$ & 3.56 & 6.14 & 1.19 & 0.20 \\
\hline$b(\%)$ & 87.41 & 85.72 & 4.87 & 0.82 \\
\hline$c(\% / \mathrm{h})$ & 6.26 & 15.60 & 2.28 & 0.045 \\
\hline $\mathrm{ED}(\%)$ & 46.88 & 66.92 & 2.72 & $<0.01$ \\
\hline
\end{tabular}

DM, dry matter; CP, crude protein; SBM, soybean meal; SEM, standard error of the mean; SSBM, solvent-extracted soybean meal; HSBM, heattreated soybean meal; DGC, dry ground corn; SFC, steam-flaked corn.

${ }^{1} \mathrm{p}=$ the disappearance rate at time $\mathrm{t}(\mathrm{h}) ; a=$ the rapidly degradable fraction in the rumen; and $b=$ the fraction slowly degraded at rate $c$ $(c>0)$. The ED was calculated assuming a passage rate $(\mathrm{kp})$ of $6 \% / \mathrm{h}$ (Tamminga et al., 1994).

et al., 1998; Zhong et al., 2008). A decreased DMI with constant milk yield was also observed in mid-lactation cows receiving SFC compared with those receiving DGC, with increased feed efficiency (5.3\%, Guyton et al., 2003). The disparity in research results may be explained by differences in forage type, the processing treatment applied to a given grain type, and starch consumption (Guyton et al., 2003).

Dietary differences in milk composition are generally reflective of differences in ruminal fermentation patterns. In the present study, milk protein content was greater for cows receiving SFC than those fed DGC $(\mathrm{p}<0.05$; Table 3$)$. Increased milk protein contents from consumption of steam-flaked grains were observed in several studies (Dhiman et al., 2002; Zhong et al., 2008), but not in others (Yu et al., 1998; Guyton et al., 2003). A meta-analysis by Ferraretto et al. (2013) showed that one percent unit of increase in rumen-degradable starch resulted in a 0.02 percentage unit increase in milk protein content. The increased milk protein content for cows fed SFC was likely 
Table 3. Effects of varying corn and soybean meal types on the productive performance and plasma metabolites in dairy cows ${ }^{1}$

\begin{tabular}{|c|c|c|c|c|c|c|c|c|}
\hline \multirow{2}{*}{ Item } & \multicolumn{2}{|c|}{ SFC } & \multicolumn{2}{|c|}{ DGC } & \multirow{2}{*}{ SEM } & \multicolumn{3}{|c|}{ p-value } \\
\hline & SSBM & HSBM & SSBM & HSBM & & Corn & SBM & Corn $\times$ SBM \\
\hline DMI (kg/d) & 22.14 & 22.73 & 23.52 & 23.11 & 0.47 & $<0.01$ & 0.76 & 0.12 \\
\hline \multicolumn{9}{|l|}{ Yield (kg/d) } \\
\hline Milk & 28.5 & 28.6 & 28.5 & 28.2 & 0.61 & 0.67 & 0.87 & 0.67 \\
\hline $4 \% \mathrm{FCM}$ & 28.6 & 28.7 & 28.5 & 28.2 & 0.88 & 0.60 & 0.73 & 0.64 \\
\hline Fat & 1.15 & 1.15 & 1.14 & 1.13 & 0.05 & 0.65 & 0.72 & 0.72 \\
\hline Protein & 0.98 & 0.97 & 0.97 & 0.96 & 0.02 & 0.85 & 0.35 & 0.74 \\
\hline Lactose & 1.41 & 1.41 & 1.40 & 1.39 & 0.03 & 0.70 & 0.83 & 0.76 \\
\hline \multicolumn{9}{|l|}{ Milk composition (\%) } \\
\hline Fat & 4.04 & 4.04 & 4.02 & 4.02 & 0.20 & 0.95 & 0.82 & 0.86 \\
\hline Protein & 3.45 & 3.45 & 3.41 & 3.40 & 0.08 & 0.04 & 0.66 & 0.47 \\
\hline Lactose & 4.94 & 4.92 & 4.92 & 4.94 & 0.04 & 0.60 & 0.83 & 0.39 \\
\hline Feed efficiency ${ }^{1}$ & 1.29 & 1.26 & 1.21 & 1.22 & 0.02 & $<0.01$ & 0.54 & 0.52 \\
\hline \multicolumn{9}{|l|}{ Plasma metabolites } \\
\hline Insulin (mIU/L) & 10.57 & 11.47 & 10.04 & 9.94 & 0.46 & 0.08 & 0.35 & 0.58 \\
\hline Glucose $(\mathrm{mmol} / \mathrm{L})$ & 3.67 & 3.69 & 3.80 & 3.80 & 0.08 & 0.44 & 0.64 & 0.52 \\
\hline
\end{tabular}

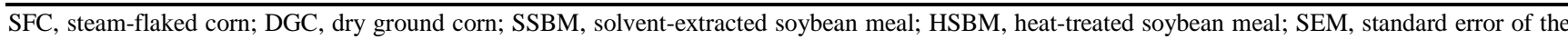
mean; SBM, soybean meal; DMI, dry matter intake; FCM, fat corrected milk.

${ }^{1}$ Feed efficiency $=$ milk yield $(\mathrm{kg}) / \mathrm{DMI}(\mathrm{kg})$.

related to the increased energy availability resulted from the increased total tract starch digestibility. Milk fat content was not influenced by corn type ( $>0.05$; Table 3$)$. Previous studies reported decreased milk fat contents and yields in cows receiving SF corn compared with cows fed DGC (Dhiman et al., 2002; Guyton et al., 2003). In the present study, there was a significant reduction in the acetate to propionate ratio for cows receiving SFC relative to cows consuming DGC ( $\mathrm{p}<0.05$; Table 4$)$, though it did not result in reduced milk fat. Lack of difference in milk fat content between corn types is probably related to the high NDF concentrations across all dietary treatments (Table 1). Variation in corn type had no effect on milk lactose content ( $>0.05$; Table 3). Milk lactose is mainly synthesized in mammary gland using glucose (Accorsi et al., 2005), while plasma glucose largely arises from hepatic gluconeogenesis using ruminally derived propionate as precursor (Huntington, 1997). In the present study, ruminal propionate and plasma glucose concentrations were not altered by corn type, which may partly explain the lack of differences in

Table 4. Effects of varying corn and soybean meal types on ruminal fermentation ( $3 \mathrm{~h}$ after morning feeding) and total tract apparent nutrient digestibility in dairy cows

\begin{tabular}{|c|c|c|c|c|c|c|c|c|}
\hline \multirow{2}{*}{ Item } & \multicolumn{2}{|c|}{ SFC } & \multicolumn{2}{|c|}{ DGC } & \multirow{2}{*}{ SEM } & \multicolumn{3}{|c|}{ p-value } \\
\hline & SSBM & HSBM & SSBM & HSBM & & Corn & SBM & Corn $\times$ SBM \\
\hline \multicolumn{9}{|l|}{ Ruminal fermentation } \\
\hline $\mathrm{pH}$ & 6.41 & 6.46 & 6.39 & 6.39 & 0.06 & 0.42 & 0.58 & 0.63 \\
\hline $\mathrm{NH}_{3}-\mathrm{N}(\mathrm{mg} / \mathrm{dL})$ & 10.4 & 10.1 & 15.7 & 13.1 & 0.96 & $<0.01$ & 0.15 & 0.24 \\
\hline Total VFA $(\mathrm{m} M)$ & 89.3 & 87.6 & 93.2 & 93.9 & 2.33 & 0.06 & 0.93 & 0.88 \\
\hline Acetate $(\mathrm{m} M)$ & 62.4 & 62.1 & 66.5 & 67.6 & 1.53 & 0.02 & 0.69 & 0.94 \\
\hline Propionate $(\mathrm{m} M)$ & 17.1 & 15.9 & 16.7 & 16.3 & 0.65 & 0.78 & 0.38 & 0.81 \\
\hline Butyrate $(\mathrm{m} M)$ & 9.7 & 9.6 & 10.0 & 10.1 & 0.32 & 0.20 & 0.97 & 0.75 \\
\hline Acetate:propionate & 3.7 & 3.9 & 4.0 & 4.2 & 0.08 & 0.02 & 0.09 & 0.82 \\
\hline \multicolumn{9}{|c|}{ Total tract apparent nutrient digestibility (\%) } \\
\hline $\mathrm{DM}$ & 69.5 & 70.7 & 69.5 & 68.3 & 0.74 & 0.20 & 0.97 & 0.20 \\
\hline $\mathrm{OM}$ & 70.9 & 72.0 & 70.9 & 69.5 & 0.76 & 0.21 & 0.88 & 0.20 \\
\hline $\mathrm{CP}$ & 70.5 & 71.0 & 71.4 & 68.9 & 0.69 & 0.43 & 0.21 & 0.06 \\
\hline $\mathrm{NDF}$ & 44.6 & 47.4 & 48.3 & 47.5 & 1.39 & 0.27 & 0.57 & 0.29 \\
\hline $\mathrm{ADF}$ & 40.4 & 43.9 & 44.4 & 43.7 & 1.48 & 0.31 & 0.46 & 0.24 \\
\hline Starch & 95.1 & 95.1 & 91.5 & 91.4 & 0.35 & $<0.01$ & 0.81 & 0.83 \\
\hline
\end{tabular}

SFC, steam-flaked corn; DGC, dry ground corn; SSBM, solvent-extracted soybean meal; HSBM, heat-treated soybean meal; SEM, standard error of the mean; SBM, soybean meal; VFA, volatile fatty acid; DM, dry matter; OM, organic matter; CP, crude protein; NDF, neutral detergent fiber; ADF, acid detergent fiber. 
milk lactose. Furthermore, the milk lactose content is controlled by the glucose uptake in the mammary gland rather than the total glucose supply (Zhao and Keating, 2007).

Substituting HSBM for SSBM increased the RUP concentration in the diet (Table 1). However, HSBM had no effects on DMI, milk yield and milk composition ( $p>0.05$, Table 3). This lack of DMI effect in association with varied SBM types is consistent with previous studies (Casper et al., 1999; Reynal and Broderick, 2003; Olmos Colmenero and Broderick, 2006). Milk composition was also generally unaffected by heat treatment of SBM in previous studies (Casper et al., 1999; Reynal and Broderick, 2003), although Olmos Colmenero and Broderick (2006) observed an increased milk lactose content after partial substitution of SSBM by HSBM. Results about milk yield from previous studies were inconsistent. Reynal and Broderick (2003) found greater milk yield from cows fed HSBM than those on SSBM, whereas in other studies (Casper et al., 1999; Olmos Colmenero and Broderick, 2006) no difference was observed in milk yield between cows fed diets based on HSBM and SSBM. The inconsistent milk yield response may be related to MP level in diets. In our study, the MP balance was about 78 to $257 \mathrm{~g}$ higher than cows' requirements. Therefore, excessive MP supply may have caused the lack of milk yield difference between SBM types. Additionally, the nonprotein nitrogen content in forage and the amino acid profile of MP may also contribute to the inconsistent milk yield response (Olmos Colmenero and Broderick, 2006).

No significant interactions for corn and SBM types were detected in plasma insulin and glucose concentrations ( $>0.05$; Table 3). Varying the corn or SBM types also had no significant effects on those two measurements ( $p>0.05)$, but insulin concentration tended to be greater for cows receiving SFC relative to DGC-fed cows $(\mathrm{p}=0.08)$. Plasma insulin concentration was related to milk protein synthesis in the mammary glands (Rius et al., 2010). DelgadoElorduy et al. (2002) reported that flaked sorghum consumption improved $\alpha$-amino $\mathrm{N}$ uptake by the mammary gland. Therefore, we may speculate that the increased insulin concentrations for cows receiving SFC would improve the milk protein synthesis, resulting in higher milk protein content compared with those fed DGC. However, further study is needed to clarify how milk protein synthesis is regulated by insulin.

\section{Ruminal fermentation and nutrient digestibility}

No significant corn and SBM-type interactions were detected for ruminal fermentation and nutrient digestibility ( $>0.05$; Table 4). Varying corn or SBM type had no effect on ruminal $\mathrm{pH}(\mathrm{p}>0.05)$. Ruminal $\mathrm{NH}_{3}-\mathrm{N}$ was greater for cows receiving DGC compared with cows fed SFC $(p<0.05)$, but was not affected by SBM type $(p>0.05$; Table 4). The lower ruminal $\mathrm{NH}_{3}-\mathrm{N}$ in cows receiving $\mathrm{SFC}$ could also be explained by the lower $\mathrm{N}$ intake, and related with the improved MCP synthesis efficiency in the rumen. Similar findings have been previously reported (Zhong et al., 2008). Substituting SSBM for HSBM resulted in similar ruminal ammonia- $\mathrm{N}(\mathrm{p}>0.05)$. This finding may be related to urea recycling to the rumen, which compensated for the lack of RDP in HSBM-based diets (Olmos Colmenero and Broderick, 2006). Recently, Gozho et al. (2008) reported that 58 to $65 \%$ (depending on treatment) of the urea $\mathrm{N}$ synthesized in the liver was returned to the gastrointestinal tract of lactating dairy cows.

Total ruminal VFA tended to be greater for cows receiving DGC relative to SFC-fed cows $(p=0.06$; Table 4$)$. Cows receiving $\mathrm{DGC}$ had greater ruminal acetate concentrations than those fed SFC $(p<0.05)$, but ruminal propionate and butyrate concentrations were similar for cows receiving either SFC or DGC ( $p>0.05)$. Therefore, the greater total VFA for DGC-fed cows was mainly attributed to the increased acetate concentration. The increased total VFA concentration for slowly fermented starch sources was also observed in mid-lactation dairy cows receiving corn in place of barley (Casper et al., 1999). In the present study, the increased acetate concentration also resulted in a greater acetate to propionate ratio for cows receiving DGC than those fed SFC $(p<0.05)$, in agreement with the findings of Guyton et al. (2003). Varying the SBM type had no effects on total and individual VFA concentration $(\mathrm{p}>0.05)$, which was in agreement with previous studies (Casper et al., 1999; Olmos Colmenero and Broderick, 2006).

Cows receiving SFC had greater apparent total tract starch digestibility than those fed DGC ( $<<0.05$; Table 4), consistent with others (Yu et al., 1998; Guyton et al., 2003; Zhong et al., 2008). However, digestibilities of DM, CP, $\mathrm{NDF}, \mathrm{ADF}$, and $\mathrm{OM}$ were not influenced by corn type ( $>0.05)$. A meta-analysis by Ferraretto et al. (2013) indicated that the increased total tract starch digestibility was primarily explained by the increased rumen starch degradability, and that post-ruminal starch digestion does not fully compensate for starch that escapes ruminal degradation. Therefore, the greater rumen starch degradability in cows receiving SFC may have contributed to the increased total tract starch digestibility relative to DGC-fed cows. In addition to the increased starch digestibility, Guyton et al. (2003) found increased DM digestibility, and Yu et al. (1998) found reduced apparent total tract $\mathrm{NDF}$ and ADF digestibility when DGC was substituted for SFC. In the present study, varying the SBM type did not affect apparent total tract nutrient digestibility ( $p>0.05)$, in agreement with findings of Olmos Colmenero 
and Broderick (2006). However, Reynal and Broderick (2003) found reduced DM, NDF, and ADF apparent total tract digestibility when cows were given diets containing HSBM in place of SSBM. These different responses in nutrient digestibility could be related to dietary composition, cow's lactation stage or other factors.

\section{Nitrogen metabolism and microbial protein yield}

In parallel with DMI, $\mathrm{N}$ intake was greater for cows receiving DGC compared with $S F C$-fed cows $(p<0.05)$, but was similar for cows receiving SSBM and HSBM ( $>>0.05$; Table 5). The $\mathrm{N}$ secretion and excretion balance measurements expressed either in $\mathrm{g} / \mathrm{d}$ or as a proportion of $\mathrm{N}$ intake (\%) were not affected by SBM type ( $>0.05)$. The excretion of fecal $\mathrm{N}(\mathrm{p}=0.07)$ tended to be greater for cows receiving DGC relative to SFC-fed cows. This trend in DGC-fed cows was likely explained by the higher $\mathrm{N}$ intake and the lower $\mathrm{N}$ utilization efficiency relative to cows receiving SFC. When expressed as a proportion of $\mathrm{N}$ intake, corn types had no effect on the proportion of $\mathrm{N}$ excreted in the urine and feces $(\mathrm{p}>0.05)$. However, milk $\mathrm{N} /$ total $\mathrm{N}$ intake was $7.0 \%$ greater $(\mathrm{p}<0.05)$ in cows fed $\mathrm{SFC}$ relative to DGC-fed cows, which was in agreement with the findings of Burkholder et al. (2004).

Significant corn and SBM type interactions were detected for BUN and MUN concentrations ( $p>0.05$; Table $5)$, but not for other $\mathrm{N}$ metabolism measurements ( $\mathrm{p}>0.05)$. Cows receiving SFC had lower BUN and MUN concentrations relative to DGC-fed cows $(p<0.05)$, indicating a more efficient $\mathrm{N}$ utilization for the SFC diet. In dairy cows, BUN largely arises from ruminal catabolism of dietary protein, with the resultant ruminal $\mathrm{NH}_{3}-\mathrm{N}$ that is not captured for MCP synthesis absorbed into portal blood and converted to urea in the liver (NRC, 2001). The BUN rapidly equilibrates with milk, resulting in a high correlation between BUN and MUN (Broderick and Clayton, 1997). In the present study, BUN and MUN had the same response when SFC was substituted for DGC. Similar results were also found by others, who reported lower MUN concentrations in cows receiving SFC than in cows fed DGC (Dhiman et al., 2002; Burkholder et al., 2004). Varying the SBM type had no effect on BUN and MUN ( $p>0.05$ ), in agreement with previous study (Reynal and Broderick, 2003).

No significant corn and SBM type interactions were detected for MCP yield ( $p>0.05$; Table 5). Although SFCfed cows had lower DMI compared with cows receiving DGC, the estimated MCP yield was similar for cows receiving SFC or DGC ( $p>0.05$ ). A previous study showed that higher carbohydrate degradation rates in the rumen increased carbon and energy availability for microbial use (Nocek and Russell, 1988). Therefore, we speculated that steam flaking corn would improve MCP synthesis efficiency under the conditions of this study. Cows receiving SSBM had greater MCP yields compared to cows receiving $\operatorname{HSBM}(\mathrm{p}<0.05)$. Energy and $\mathrm{N}$ are the nutritional factors that most often limit microbial growth and milk production (Clark et al., 1992). Therefore, it is not hard to understand that SSBM-based diets resulted in more MCP synthesis by rumen microbes because SSBM contains more RDP than HSBM as shown in Table 1 and 2, even though Olmos Colmenero and Broderick (2006) reported similar MCP yields when the cows received HSBM or SSBM.

\section{CONCLUSIONS}

The SFC-fed cows had lower DMI and total $\mathrm{N}$ intake than DGC-fed cows. However, milk and milk protein yields

Table 5. Effects of varying corn and soybean meal types on nitrogen $(\mathrm{N})$ metabolism and MCP yield in dairy cows

\begin{tabular}{|c|c|c|c|c|c|c|c|c|}
\hline \multirow{2}{*}{ Item } & \multicolumn{2}{|c|}{ SFC } & \multicolumn{2}{|c|}{ DGC } & \multirow{2}{*}{ SEM } & \multicolumn{3}{|c|}{$\mathrm{p}$-value } \\
\hline & SSBM & HSBM & SSBM & HSBM & & Corn & SBM & Corn $\times$ SBM \\
\hline \multicolumn{9}{|l|}{$\mathrm{N}$ balance $(\mathrm{g} / \mathrm{d})$} \\
\hline $\mathrm{N}$ intake & 553.3 & 566.1 & 591.8 & 579.4 & 11.7 & $<0.01$ & 0.98 & 0.10 \\
\hline Fecal N & 162.5 & 162.1 & 171.7 & 178.4 & 5.1 & 0.07 & 0.65 & 0.61 \\
\hline Urinary $\mathrm{N}$ & 180.8 & 197.8 & 213.3 & 196.0 & 7.6 & 0.22 & 0.99 & 0.17 \\
\hline Milk N & 156.7 & 157.7 & 154.7 & 153.3 & 3.4 & 0.37 & 0.95 & 0.75 \\
\hline $\mathrm{N}$ retention & 53.3 & 48.7 & 52.2 & 51.8 & 12.6 & 0.94 & 0.84 & 0.87 \\
\hline \multicolumn{9}{|c|}{ As proportion of $\mathrm{N}$ intake (\%) } \\
\hline Fecal N & 29.4 & 28.6 & 29.1 & 30.8 & 0.67 & 0.40 & 0.67 & 0.25 \\
\hline Urinary $\mathrm{N}$ & 32.8 & 35.0 & 36.2 & 33.7 & 1.08 & 0.60 & 0.96 & 0.26 \\
\hline Milk N & 28.4 & 27.9 & 26.1 & 26.5 & 0.45 & $<0.01$ & 0.89 & 0.38 \\
\hline \multicolumn{9}{|l|}{ Urea N (mg/dL) } \\
\hline In blood & 15.8 & 17.1 & 18.9 & 17.6 & 0.51 & $<0.01$ & 0.89 & $<0.01$ \\
\hline In milk & 11.6 & 12.5 & 13.6 & 13.5 & 0.27 & $<0.01$ & 0.13 & 0.05 \\
\hline MCP yield $(\mathrm{kg} / \mathrm{d})$ & 2.2 & 2.0 & 2.4 & 2.0 & 0.14 & 0.62 & 0.05 & 0.83 \\
\hline
\end{tabular}

MCP, microbial protein; SFC, steam-flaked corn; DGC, dry ground corn; SSBM, solvent-extracted soybean meal; HSBM, heat-treated soybean meal; SEM, standard error of the mean; SBM, soybean meal. 
were not influenced by corn type, resulting in higher efficiency of utilization of feed and $\mathrm{N}$ for the cows receiving SFC than DGC-fed cows. Compared with SSBMfed cows, cows receiving HSBM had lower MCP yields, but similar total tract apparent nutrient digestibility, $\mathrm{N}$ metabolism, and productivity. Excessive MP supply from the diets may have caused the lack of productivity response between SBM types. Results of the present study indicated that increasing the energy degradability in the rumen could improve feed and $\mathrm{N}$ utilization, thereby ameliorating environmental pollution under the condition of this study.

\section{IMPLICATIONS}

Feed utilization efficiency in modern dairy farming is low, leading to not only waste of important feed resource but also serious environmental pollution. Dietary protein degradability in the rumen is unlikely to have notable effects on rumen fermentation, nitrogen metabolism and productivity in mid-lactation dairy cows. However, dietary energy degradability had a great influence on these measurements. Increasing dietary energy degradability in the rumen could feasibly improve feed and $\mathrm{N}$ utilization and reduce environmental pollution.

\section{ACKNOWLEDGMENTS}

This work was supported by the National Basic Research Program of China, Ministry of Science and Technology, P. R. China (Grant No. 2011CB100801). The authors acknowledge the personnel of the Hangzhou Hangjiang Dairy Farm for their assistance with animal care, the staff of the Institute of Dairy Science for their technical assistance, and Prof. Dr. Kyu-Ho Myung from Chonnam National University, Republic of Korea for providing critical review and suggestions for manuscript improvement.

\section{REFERENCES}

Accorsi, P. A., M. Gamberoni, G. Isani, N. Govoni, R. Viggiani, M. Monari, M. DE Ambrogi, A. Munno, C. Tamanini, and E. Seren. 2005. Leptin does not seem to influence glucose uptake by bovine mammary explants. J. Physiol. Pharmacol. 56:689698.

AOAC (Association of Official Analytical Chemists). 1990. Official Methods of Analysis. Vol. 1. 15th ed. AOAC, Arlington, VA, USA.

Bach, A., S. Calsamiglia, and M. D. Stern 2005. Nitrogen metabolism in the rumen. J. Dairy Sci. 88:E9-E21.

Barham, D. and P. Trinder. 1972. An improved color reagent for the determination of blood glucose by the oxidase system. Analyst 97:142-145.

Bertrand, A., Y. Castonguay, P. Nadeau, S. Laberge, R. Michaud, G. Belanger, and P. Rochette. 2003. Oxygen deficiency affects carbohydrate reserves in overwintering forage crops. J. Exp. Bot. 54:1721-1730.

Broderick, G. A. and M. K. Clayton. 1997. A statistical evaluation of animal and nutritional factors influencing concentrations of milk urea nitrogen. J Dairy Sci. 80:2964-2971.

Burkholder, K. M., A. D. Guyton, J. M. McKinney, and K. F. Knowlton. 2004. The effect of steam flaked or dry ground corn and supplemental phytic acid on nitrogen partitioning in lactating cows and ammonia emission from manure. J. Dairy Sci. 87:2546-2553.

Calsamiglia, S., A. Ferret, C. K. Reynolds, N. B. Kristensen, and A M. van Vuuren. 2010. Strategies for optimizing nitrogen use by ruminants. Animal 4:1184-1196.

Casper, D. P., H. A. Maiga, M. J. Brouk, and D. J. Schingoethe. 1999. Synchronization of carbohydrate and protein sources on fermentation and passage rates in dairy cows. J. Dairy Sci. 82:1779-1790.

Chaney, A. L., and E. P. Marbach. 1962. Modified reagents for determination of urea and ammonia. Clin. Chem. 8:130-132.

Chen, X. B. and M. J. Gomes. 1992. Estimation of Microbial Protein Supply to Sheep and Cattle Based on Urinary Excretion of Purine Derivatives - An Overview of the Technical Details. International Feed Resources Unit, Rowett Research Inst., Bucksburn, Aberdeen, AB2 9SB, UK. Occasional Publication.

Clark, J. H., T. H. Klusmeyer, and M. R. Cameron. 1992. Microbial protein synthesis and flows of nitrogen fractions to the duodenum of dairy cows. J. Dairy Sci. 75:2304-2323.

Daniels, K. M., S. R. Hill, K. F. Knowlton, R. E. James, M. L. McGilliard, and R. M. Akers. 2008. Effects of milk replacer composition on selected blood metabolites and hormones in preweaned Holstein heifers. J. Dairy Sci. 91:2628-2640.

Delgado-Elorduy, A., C. B. Theurer, J. T. Huber, A. Alio, O. Lozano, M. Sadik, P. Cuneo, H. D. De Young, I. J. Simas, J. E. Santos, L. Nussio, C. Nussio, K. J. Webb, and H. Tagari. 2002. Splanchnic and mammary nitrogen metabolism by dairy cows fed dry-rolled or steam-flaked sorghum grain. J. Dairy Sci. $85: 148-159$.

Dewhurst, R. J. and D. R. Davies, and R. J. Merry. 2000. Microbial protein supply from the rumen. Anim. Feed Sci. Technol. 85:1-21.

Dhiman, T. R., M. S. Zaman, I. S. MacQueen, and R. L. Boman. 2002. Influence of corn processing and frequency of feeding on cow performance. J. Dairy Sci. 85:217-226.

Ferraretto, L. F. and P. M. Crump, and R. D. Shaver. 2013. Effect of cereal grain type and corn grain harvesting and processing methods on intake, digestion, and milk production by dairy cows through a meta-analysis. J. Dairy Sci. 96:533-550.

Guyton, A. D., J. M. McKinney, and K. F. Knowlton. 2003. The effect of steam-flaked or dry ground corn and supplemental phytic acid on phosphorus partitioning and ruminal phytase activity in lactating cows. J. Dairy Sci. 86:3972-3982.

Gozho, G. N., M. R. Hobin, and T. Mutsvangwa. 2008. Interactions between barley grain processing and source of supplemental dietary fat on nitrogen metabolism and ureanitrogen recycling in dairy cows. J. Dairy Sci. 91:247-259.

Hall, M. B. and G. B. Huntington. 2008. Nutrient synchrony: Sound in theory, elusive in practice. J. Anim. Sci. 86(14 
Suppl): E287-E292.

Henning, P. H. and D. G. Steyn, and H. H. Meissner. 1993. Effect of synchronization of energy and nitrogen supply on ruminal characteristics and microbial growth. J. Anim. Sci. 71:25162528.

Hu, W. L., J. X. Liu, J. A. Ye, Y. M. Wu, and Y. Q. Guo. 2005. Effect of tea saponin on rumen fermentation in vitro. Anim. Feed Sci. Technol. 120:333-339.

Huntington, G. B. 1997. Starch utilization by ruminants: from basics to the bunk. J. Anim. Sci. 75:852-867.

Ministry of Agriculture of P. R. China. 2004. Feeding Standard of Dairy Cattle (NY/T 34-2004). Ministry of Agriculture of P. R. China, Beijing, China.

National Research Council. 2001. Nutrient Requirements of Dairy Cattle. 7th rev. ed. Natl. Acad. Sci., Washington, DC, USA.

Nocek, J. E. and J. B. Russell. 1988. Protein and energy as an integrated system. Relationship of ruminal protein and carbohydrate availability to microbial synthesis and milk production. J. Dairy Sci. 71:2070-2107.

Olmos Colmenero, J. J. and G. A. Broderick. 2006. Effect of amount and ruminal degradability of soybean meal protein on performance of lactating dairy cows. J. Dairy Sci. 89:16351643.

Ørskov, E. R., F. D. D. Hovell, and F. Mould. 1980. The use of the nylon bag technique for the evaluation of feedstuffs. Trop. Anim. Prod. 5:195-213.

Oser, B. L. 1965. Hawk's Physiological Chemistry. 14th ed. McGraw-Hill, New York, NY, USA.

Rahmatullah, M. and T. R. Boyde. 1980. Improvements in the determination of urea using diacetyl monoxime; methods with and without deproteinisation. Clin. Chim. Acta 107:3-9.

Reynal, S. M. and G. A. Broderick. 2003. Effects of feeding dairy cows protein supplements of varying ruminal degradability. J. Dairy Sci. 86:835-843.

Rius, A. G., J. A. R. N. Appuhamy, J. Cyriac, D. Kirovski, O. Becvar, J. Escobar, M. L. McGilliard, B. J. Bequette, R. M. Akers, and M. D. Hanigan. 2010. Regulation of protein synthesis in mammary glands of lactating dairy cows by starch and amino acids. J. Dairy Sci. 93:3114-3127.

Rooney, L. W. and R. L. Pflugfeder. 1986. Factors affecting starch digestibility with special emphasis on sorghum and corn. J. Anim. Sci. 63:1607-1623.
Rotger, A., A. Ferret, S. Calsamiglia, and X. Manteca. 2006. Effects of nonstructural carbohydrates and protein sources on intake, apparent total tract digestibility, and ruminal metabolism in vivo and in vitro with high-concentrate beef cattle diets. J. Anim. Sci. 84:1188-1196.

Shen, J. S., Z. Chai, L. J. Song, J. X. Liu, and Y. M. Wu. 2012. Insertion depth of oral stomach tubes may affect the fermentation parameters of ruminal fluid collected in dairy cows. J. Dairy Sci. 95:5978-5984.

Sinclair, K. D., P. C. Garnsworthy, G. E. Mann, and L. A. Sinclair. 2014. Reducing dietary protein in dairy cow diets: implications for nitrogen utilization, milk production, welfare and fertility. Animal 8:262-274.

Sinclair, L. A., P. C. Garnsworthy, J. R. Newbold, and P. J. Buttery. 1993. Effect of synchronizing the rate of dietary energy and nitrogen release on rumen fermentation and microbial protein synthesis in sheep. J. Agric. Sci. 120:251-263.

Tamminga, S., W. M. Vanstraalen, A. P. J. Subnel, R. G. M. Meijer, A. Steg, C. J. G. Wever, and M. C. Blok. 1994. The dutch protein evaluation system: The DVE/OEB-system. Livest. Prod. Sci. 40:139-155.

Valadares, R. F. D., G. A. Broderick, S. C. Valadares Filho, and M. K. Clayton. 1999. Effect of replacing alfalfa silage with high moisture corn on ruminal protein synthesis estimated from excretion of total purine derivatives. J. Dairy Sci. 82:26862696.

Van Keulen, V. and B. H. Young. 1977. Evaluation of acidinsoluble ash as a natural marker in ruminant digestibility studies. J. Anim. Sci. 44:282-287.

Van Soest, P. J., J. B. Robertson, and B. A. Lewis. 1991. Methods for dietary fiber, neutral detergent fiber, and nonstarch polysaccharides in relation to animal nutrition. J. Dairy Sci. 74:3583-3597.

Yu, P., J. T. Huber, F. A. P. Santos, J. M. Simas, and C. B. Theurer. 1998. Effects of ground, steam-flaked, and steam-rolled corn grains on performance of lactating cows. J. Dairy Sci. 81:777783.

Zhao, F. Q. and A. F. Keating. 2007. Expression and regulation of glucose transporters in the bovine mammary gland. J. Dairy Sci. 90(E. Suppl.):E76-E86.

Zhong, R. Z., J. G. Li, Y. X. Gao, Z. L. Tan, and G. P. Ren. 2008. Effects of substitution of different levels of steam-flaked corn for finely ground corn on lactation and digestion in early lactation dairy cows. J. Dairy Sci. 91:3931-3937. 